\section{Performance of Methyl Bromide Alternatives in Strawberry}

\author{
James P. Gilreath ${ }^{1,2}$, Bielinski M. Santos ${ }^{1,3,5}$, and \\ Timothy N. Motis ${ }^{1,4}$
}

AdDitional INDEX wORDs. Fragaria $\times$ ananassa, Belonolaimus, sting nematode 1,3-dichloropropene, chloropicrin, metam sodium, fosthiazate, furfural, isothiocyanate

SUMMARY. Field studies were conducted to compare the performance of several methyl bromide (MBr) alternative programs on sting nematode (Belonolaimus spp.) control and marketable yield of 'Camarosa' strawberry (Fragaria $\times$ ananassa). The tested fumigation programs were 1 ) $\mathrm{MBr}+$ chloropicrin $(\mathrm{Pic} ; 67: 33 \mathrm{v} / \mathrm{v}$ ) at $350 \mathrm{lb} / \mathrm{acre}, 2) \mathrm{Pic}+$ metam sodium $(\mathrm{MNa})$ at $300 \mathrm{lb} /$ acre and $37.5 \mathrm{gal} / \mathrm{acre}, 3)$ 1,3-dichloropropene (1,3-D) + Pic at $35 \mathrm{gal} / \mathrm{acre}, 4)$ 1,3-D + Pic and dazomet at $35 \mathrm{gal} / \mathrm{acre}$ and $200 \mathrm{lb} / \mathrm{acre}, 5)$ propylene oxide at $45 \mathrm{gal} / \mathrm{acre}, 6)$ furfural + allyl isothiocyanate (AITC) at $600 \mathrm{lb} / \mathrm{acre}, 7$ ) furfural and MNa at 56 and $50 \mathrm{gal} / \mathrm{acre}, \mathbf{8}$ ) furfural + AITC at $400 \mathrm{lb} /$ acre followed by four furfural applications of $6 \mathrm{gal} / \mathrm{acre} /$ injection, 9) furfural and $\mathrm{MNa}$ at 37 and $33 \mathrm{gal} / \mathrm{acre}$ followed by four furfural applications of $6 \mathrm{gal} / \mathrm{acre} / \mathrm{injection,} \mathrm{10)} \mathrm{fosthiazate} \mathrm{and}$ Pic at 4.5 and $150 \mathrm{lb} / \mathrm{acre}$, and 11 ) a nontreated control. The fumigation programs consisting of 1,3-D + Pic and dazomet, 1,3-D + Pic, Pic and $\mathrm{MNa}$, and fosthiazate and Pic proved to be as valuable as the grower-standard $\mathrm{MBr}+\mathrm{Pic}$ on strawberry plant vigor, sting nematode control, and early and total marketable yields.

S trawberry production in Florida occurs between October and March on $\approx 7100$ acres, with a reported value of $\approx \$ 180$ million (U.S. Department of Agriculture, 2005). Sting nematode is one of the most economically important soilborne pests in strawberry production (Noling, 2005). In Florida, it is a limiting factor for successful growth and yields, causing significant injuries to root tips, hence decreasing the plant's ability to absorb water and nutrients (Noling, 2005). Affected fields initially show localized and uneven growth with chlorotic plants, eventually extending the damage to the whole planted area (Jardine and Todd, 1990).

Florida strawberries are grown using the annual hill system, where beds are pressed and fumigated before placing drip irrigation lines and polyethylene mulch (Peres et al., 2006). Soil fumigation with methyl bromide $(\mathrm{MBr})$ was an effective

\footnotetext{
We thank the financial and in-kind support of the IR-4 program, and Chancey Farms of Dover, FL.

${ }^{\mathrm{I}}$ Gulf Coast Research and Education Center, IFAS, University of Florida, 14625 CR 672, Wimauma, FL

${ }^{2}$ Former Professor of Weed Science.

${ }^{3}$ Assistant Professor of Horticulture.

${ }^{4}$ Former Research Associate.
}

${ }^{5}$ Corresponding author. E-mail: bmsantos@ufl.edu. means of controlling sting nematode populations. However, this fumigant has been phased out in compliance with the Montreal Protocol, because it is an ozone-depleting molecule (Watson et al., 1992). One of the leading $\mathrm{MBr}$ alternatives is 1,3 dichloropropene (1,3-D) + chloropicrin (Pic), which merges the nematicidal activity of $1,3-\mathrm{D}$ with the fungicide Pic and has shown to be an effective means to control soilborne diseases and nematodes in tomato (Lycopersicon esculentum) (Gilreath et al., 2004; Jones et al., 1995). In strawberry nurseries, De Cal et al., (2004) found that Pic and 1,3-D were comparable with $\mathrm{MBr}$ for soil-borne disease control. Bell pepper (Capsicum annuиm) research revealed effective nematode control under mulched beds with preplant applications of 1,3-D + Pic (Eger, 2000; Mirusso et al., 2002).

Dazomet, metam sodium $(\mathrm{MNa})$ and allyl isothiocyanate (AITC) break down in the soil, producing isothiocyanate, which is a potent biocide (Ajwa et al., 2003b; Rodriguez-Kabana (2005)). Commercially, dazomet is mostly sold as solid granules and powder, which must be incorporated into the soil to initiate activation, whereas $\mathrm{MNa}$ and AITC are available in liquid formulations, providing application flexibility because they can be either directly sprayed on the soil and incorporated or drip injected. Previous studies suggested that MNa could be inconsistent in soil-borne pest control (Fennimore et al., 2003; Locascio et al., 1997), whereas other research has found that it can be a viable $\mathrm{MBr}$ alternative (Ajwa et al., 2003a). Despite these discrepancies, $\mathrm{MNa}$ is a relatively low-cost product that could be soil sprayed or drip applied, and further research is necessary to determine its efficacy in combination with other fumigants.

Propylene oxide is an all-purpose fumigant of broad-spectrum control against soil-borne diseases, nematodes, and weeds (López-Aranda et al., 2004; Norton, 2004). After soil application, it is microbially decomposed and transformed to propylene glycol, a food additive (Warren, 2004). In tomato, sting nematode populations rapidly decreased at $570 \mathrm{~L} \cdot \mathrm{ha}^{-1}$ or higher (Santos and Gilreath, 2005 ). Furfural, a natural byproduct of sugarcane (Saccharum officinarum) processing, is another molecule proposed by Rodriguez-Kabana (2005) as an effective $\mathrm{MBr}$ alternative to control nematodes in greenhouse studies. Despite all these studies, little information exists on the effect of combinations of soil fumigants on sting nematode control and on

\begin{tabular}{llll}
\hline $\begin{array}{l}\text { Units } \\
\begin{array}{l}\text { To convert U.S. to SI, } \\
\text { multiply by }\end{array}\end{array}$ & U.S. unit & SI unit & $\begin{array}{l}\text { To convert SI to U.S., } \\
\text { multiply by }\end{array}$ \\
\hline 29.5735 & $\mathrm{fl} \mathrm{oz}$ & $\mathrm{mL}$ & 0.0338 \\
0.3048 & $\mathrm{ft}$ & $\mathrm{m}$ & 3.2808 \\
3.7854 & $\mathrm{gal}$ & $\mathrm{L}$ & 0.2642 \\
0.1242 & $\mathrm{gal} / 100 \mathrm{ft}$ & $\mathrm{L} \cdot \mathrm{m}^{-1}$ & 8.0520 \\
9.3540 & $\mathrm{gal} / \mathrm{acre}$ & $\mathrm{L} \cdot \mathrm{ha}^{-1}$ & 0.1069 \\
2.54 & inch $(\mathrm{es})$ & $\mathrm{cm}$ & 0.3937 \\
1.1209 & lb/acre & $\mathrm{kg} \cdot \mathrm{ha}^{-1}$ & 0.8922 \\
0.0254 & mil & $\mathrm{mm}$ & 39.3701 \\
2.2417 & ton/acre & $\mathrm{t} \cdot \mathrm{ha}^{-1}$ & 0.4461
\end{tabular}


strawberry yield. Therefore, the objective of this study was to compare promising $\mathrm{MBr}$ alternatives for soil fumigation in Florida strawberry.

\section{Materials and methods}

Studies were conducted in two locations in west-central Florida during the 2002-2003 strawberry season. The experimental plots were established at Chancey Farms and at the Gulf Coast Research and Education Center of the University of Florida, located in Dover and Bradenton respectively. Predominant soils in both locations are deep-sand spodosols with organic matter content of less than $2 \%$ and a $\mathrm{pH}$ between 7.1 and 7.4. Both experimental sites have a history of moderate to heavy sting nematode infestations, which can severely limit crop yield when they are not controlled.

Eleven treatments were distributed in a randomized complete-block design with six replications. The fumigation programs were 1) $\mathrm{MBr}+$ Pic $(67: 33 \mathrm{v} / \mathrm{v})$ at $350 \mathrm{lb} / \mathrm{acre} ; 2)$ $\mathrm{Pic}+\mathrm{MNa}$ at $300 \mathrm{lb} /$ acre and 37.5 gal/acre respectively; 3 ) $1,3-\mathrm{D}+\mathrm{Pic}$ at $35 \mathrm{gal} / \mathrm{acre}$; 4) 1,3-D + Pic and dazomet at $35 \mathrm{gal} / \mathrm{acre}$ and $200 \mathrm{lb} /$ acre respectively; 5) propylene oxide at $45 \mathrm{gal} / \mathrm{acre} ; 6$ ) furfural + AITC at $600 \mathrm{lb} / \mathrm{acre}$; 7) furfural and $\mathrm{MNa}$ at rates of 56 and $50 \mathrm{gal} / \mathrm{acre}$ respectively; 8) furfural + AITC at $400 \mathrm{lb} /$ acre followed by four furfural applications of $6 \mathrm{gal} /$ acre per injection; 9) furfural and $\mathrm{MNa}$ at rates of 37 and $33 \mathrm{gal} /$ acre respectively, followed by four furfural applications of $6 \mathrm{gal} /$ acre per injection; 10) fosthiazate and Pic at rates of 4.5 and $150 \mathrm{lb} /$ acre respectively; and 11) a nontreated control.

Before fumigant application, the soil was prebedded and starter fertilizer $(200 \mathrm{lb} /$ acre of $15 \mathrm{~N}-0 \mathrm{P}-24.9 \mathrm{~K})$ was applied on bed tops and immediately rototilled within the top 6 inches of the soil. Twenty-one days before transplanting, $\mathrm{MBr}+\mathrm{Pic}, \mathrm{Pic}, \mathrm{1}, 3-\mathrm{D}+$ Pic, and propylene oxide were injected about 6 inches deep into the finished beds using a nitrogen-gaspropelled fumigation rig with three chisels per bed. Fumigant delivery was controlled by flowmeters, which were calibrated to deliver the desired amounts of the fumigants. In plots treated with $1,3-\mathrm{D}+\mathrm{Pic}$ and dazomet, the latter was applied on the surface of the finished beds with a conventional fertilizer spreader, and watered twice on the same day with $6789 \mathrm{gal} / \mathrm{acre} / \mathrm{application}$ to enhance fumigant release, whereas 1,3-D + Pic was injected the following day. Furfural, furfural + AITC, $\mathrm{MNa}$, and fosthiazate were drip injected through three irrigation lines ( $0.45 \mathrm{gal} / \mathrm{min} / 100 \mathrm{ft}$ of bed; T-Tape Systems International, San Diego, CA) buried 1 inch deep, and dissolved in a volume of $27,154 \mathrm{gal} / \mathrm{acre} /$ application. The Pic and MNa were injected at 21 and $14 \mathrm{~d}$ before transplanting respectively. Fosthiazate was applied $3 \mathrm{~d}$ before transplanting. The first application of furfural + AITC and furfural and $\mathrm{MNa}$ occurred $14 \mathrm{~d}$ before transplanting, and the four subsequent applications took place at $4,7,11,15$, and 18 weeks after transplanting (WAT).

Planting beds were 24 inches wide on the top, 28 inches wide on the base, and 10 inches tall, and they were covered with black high-density polyethylene mulch (1.25 mil thick; Pliant Corp., Schaumburg, IL). In Dover, experimental units consisted of a single $45-\mathrm{ft}$ plot, whereas in Bradenton the plots were $50 \mathrm{ft}$ long. Bare-root 'Camarosa' strawberry transplants $(\approx 10$ inches tall $)$, obtained from a commercial strawberry nursery in North Carolina, were planted in double rows separated 12 inches apart, and with an in-row spacing of 15 inches. Within $1 \mathrm{~h}$ after transplanting, the experimental sites were sprinkler irrigated between 6 and $8 \mathrm{~h}$ per day for $\approx 2$ weeks. This procedure helps to provide enough moisture to the soil through the planting holes and row middles to ensure proper transplant establishment. Irrigation, drip fertilization, frost protection, and insecticide and fungicide applications followed recommended commercial practices for Florida strawberry production (Peres et al., 2006).

Sting nematode populations were determined at 10,13 , and 17 WAT by extracting soil samples with a soil probe ( 1 inches wide by 8 inches deep) from the rhizosphere of 20 strawberry plants per plot, and the nematodes were separated and counted from $100 \mathrm{~mL}$ soil using a standard sieving and centrifugation procedure (Jenkins, 1964). At both locations, strawberry plant vigor was estimated at 8 and 13 WAT. Plant vigor was determined using a scale from $0 \%$ to $100 \%$, where $0 \%$ equals plant death and $100 \%$ indicates optimum growth. The latter was defined as strawberry plants with fully developed foliage, flowers and fruits according to their vegetative stage, and plants free of leaf deformations, chlorosis, or damage. To assess plant vigor, treatments were compared within each replication. Marketable fruit weight was collected twice per week, resulting in 19 and 22 harvests in Dover and Bradenton respectively. Fruit harvests began about at 7 WAT. Early fruit yield was determined by adding the marketable fruit weights from all the December and January harvests.

Plant vigor values were expressed as percentages and transformed with arc sine square root before analysis of variance to normalize the treatment means, whereas the sting nematode populations were transformed with $\log _{10}$ (observation +1 ) before analysis of variance. The significance of the main effects and of the treatment-by-location interaction on each variable were examined with analysis of variance $(P=0.05)$. When significant differences were obtained, treatment means were separated using the Waller-Duncan multiple comparison procedure (SAS version 8; SAS Institute, Cary, NC).

\section{Results and discussion}

There was no significant treatment-by-location interaction for each variable. Therefore, only the data from the Dover location are discussed. Fumigant programs significantly affected sting nematode populations at 10,13 , and 17 WAT. At 10 WAT, the treatments with the combinations of $\mathrm{MBr}+\mathrm{Pic}, \mathrm{Pic}$ and $\mathrm{MNa}, 1,3-\mathrm{D}+\mathrm{Pic}$, and 1,3-D + Pic and dazomet were equally effective against sting nematode, with populations ranging between one and four juveniles per 100 $\mathrm{mL}$ soil (Table 1 ). At the same time, the first three combinations provided the same nematode control as the combined program of fosthiazate and Pic. Soil samples collected 3 weeks later revealed a similar sting nematode response to the fumigants, with the highest populations in all four treatments containing furfural, the nontreated control, and propylene oxide. At 17 WAT, there were 
two well-defined groups of treatments with regard to sting nematode Pic and dazomet, 1,3-D + Pic, Pic and $\mathrm{MNa}$, fosthiazate and Pic, and $\mathrm{MBr}+$ Pic drastically reduced sting nematode populations to less than 20 juveniles per $100 \mathrm{~mL}$ soil, whereas the remaining treatments had a similar performance against sting nematode as the nontreated control.

Strawberry plant vigor at 8 and 13 WAT was influenced by the application of the soil fumigants (Table 2 ). control. The combinations of $1,3-\mathrm{D}+$

Plants in plots treated with either 1,3-D + Pic and dazomet, 1,3-D + $\mathrm{Pic}$ Pic and $\mathrm{MNa}$, fosthiazate and Pic, or $\mathrm{MBr}+\mathrm{Pic}$ were the most vigorous $(\geq 78 \%)$ at 8 WAT, whereas the rest of the treatments were mostly less than $50 \%$ vigor. A similar trend continued throughout the growing season, as revealed by plant vigor readings taken at 13 WAT. Interestingly, the treatments with the highest plant vigor at 13 WAT were the same with the highest sting nematode control, which likely suggests that there is a

Table 1. Influence of soil fumigants on sting nematode populations at 10, 13, and 17 weeks after transplanting (WAT) in strawberry fields at Dover, FL, in 2002-03.

\begin{tabular}{|c|c|c|c|c|}
\hline \multirow[b]{2}{*}{ Fumigants $^{\mathrm{z}}$} & \multirow[b]{2}{*}{ Rate (units/acre) ${ }^{\mathrm{y}}$} & \multicolumn{3}{|c|}{ 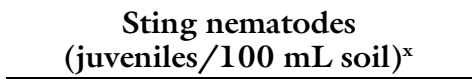 } \\
\hline & & $10 \mathrm{WAT}$ & 13 WAT & $17 \mathrm{WAT}$ \\
\hline Nontreated control & - & $12 \mathrm{abc}$ & $25 \mathrm{a}$ & $57 \mathrm{a}$ \\
\hline $\mathrm{MBr}+\mathrm{Pic}$ & $350 \mathrm{lb}$ & 4 cde & $6 \mathrm{de}$ & $4 \mathrm{bc}$ \\
\hline Pic and $\mathrm{MNa}$ & $300 \mathrm{lb}+37.5 \mathrm{gal}$ & 4 de & $6 \mathrm{cde}$ & $6 \mathrm{bc}$ \\
\hline $1,3-\mathrm{D}+\mathrm{Pic}$ & $35 \mathrm{gal}$ & 2 de & $4 \mathrm{de}$ & $4 \mathrm{bc}$ \\
\hline $1,3-\mathrm{D}+$ Pic and dazomet & $35 \mathrm{gal}+200 \mathrm{lb}$ & le & $2 \mathrm{e}$ & $1 \mathrm{c}$ \\
\hline Propylene oxide & $45 \mathrm{gal}$ & $18 \mathrm{abc}$ & $22 \mathrm{a}$ & $45 \mathrm{a}$ \\
\hline Furfural + AITC & $600 \mathrm{lb}$ & $23 \mathrm{ab}$ & $42 \mathrm{a}$ & $60 \mathrm{a}$ \\
\hline Furfural and $\mathrm{MNa}$ & $56 \mathrm{gal}+50 \mathrm{gal}$ & $22 \mathrm{ab}$ & $26 \mathrm{a}$ & $36 a$ \\
\hline Furfural + AITC & $400 \mathrm{lb}$ & $12 \mathrm{ab}$ & $16 \mathrm{abc}$ & 49 a \\
\hline Furfural (four times) & $6 \mathrm{gal}$ & & & \\
\hline Furfural and $\mathrm{MNa}$ & $37 \mathrm{gal}+33 \mathrm{gal}$ & $26 \mathrm{a}$ & $20 \mathrm{ab}$ & $50 \mathrm{a}$ \\
\hline Furfural (four times) & $6 \mathrm{gal}$ & & & \\
\hline Fosthiazate and Pic & $4.5 \mathrm{lb}+150 \mathrm{lb}$ & $6 \mathrm{bcd}$ & $13 \mathrm{bcd}$ & $18 \mathrm{~b}$ \\
\hline
\end{tabular}

close relationship between root nematode infestations and growth reduction in strawberry.

Both early and total marketable strawberry fruit weights were affected by the application of fumigants. The lowest early fruit yields were obtained in plots treated with propylene oxide, the nontreated control, and the four programs that included furfural (Table 2). The combinations of 1,3D + Pic and dazomet, 1,3-D + Pic, Pic and $\mathrm{MNa}$, and fosthiazate and Pic proved to be as valuable as the grower-standard $\mathrm{MBr}+\mathrm{Pic}$, with early fruit weights ranging between 2.50 and 2.94 tons/acre. With regard to total fruit weight, the same promising treatments previously described had the highest total yields, averaging $\approx 11$ tons/acre (Table 2).

Previous research has demonstrated that $1,3-\mathrm{D}+$ Pic is comparable with $\mathrm{MBr}+\mathrm{Pic}$ for nematode control in vegetable crops, which agrees with the results found in the current study (Gilreath et al., 2004). Similarly, Gilreath et al. (2005), in discussing a long-term study of fumigants on bell pepper, found that $\mathrm{MNa}+$ Pic was equally effective as $\mathrm{MBr}+\mathrm{Pic}$ in bell pepper for sting nematode control, and provided similar fruit weight. Although high rates of propylene oxide have shown promising results against sting nematode populations in tomato (Santos and Gilreath, 2005), this fumigant underperformed for strawberry in this experiment. A similar situation occurred with

Table 2. Influence of soil fumigants on strawberry plant vigor at 8 and 13 weeks after transplanting (WAT), and early and total marketable yield in Dover, FL, in 2002-03.

\begin{tabular}{|c|c|c|c|c|c|}
\hline \multirow[b]{2}{*}{ Fumigants $^{\mathrm{z}}$} & \multirow[b]{2}{*}{ Rate (units/acre) ${ }^{\mathrm{y}}$} & \multicolumn{2}{|c|}{ Plant vigor $(\%)^{\mathrm{x}}$} & \multirow{2}{*}{$\begin{array}{l}\text { Early yield } \\
\text { (tons } / \text { acre) }^{\mathrm{y}}\end{array}$} & \multirow{2}{*}{$\begin{array}{c}\text { Total yield } \\
\left(_{\text {tons } / \text { acre })^{\mathrm{y}}}\right.\end{array}$} \\
\hline & & 8 WAT & $13 \mathrm{WAT}$ & & \\
\hline Nontreated control & - & 30 def & $17 \mathrm{~d}$ & $0.83 \mathrm{ef}$ & $2.52 \mathrm{e}$ \\
\hline Pic and $\mathrm{MNa}$ & $300 \mathrm{lb}+37.5 \mathrm{gal}$ & $82 \mathrm{a}$ & $80 \mathrm{a}$ & $2.81 \mathrm{a}$ & $11.11 \mathrm{a}$ \\
\hline $1,3-\mathrm{D}+\mathrm{Pic}$ & $35 \mathrm{gal}$ & $82 \mathrm{a}$ & $81 \mathrm{a}$ & $2.89 \mathrm{a}$ & $11.21 \mathrm{a}$ \\
\hline $1,3-\mathrm{D}+$ Pic and dazomet & $35 \mathrm{gal}+200 \mathrm{lb}$ & $78 \mathrm{a}$ & $84 \mathrm{a}$ & $2.94 \mathrm{a}$ & $11.80 \mathrm{a}$ \\
\hline Furfural and $\mathrm{MNa}$ & $56 \mathrm{gal}+50 \mathrm{gal}$ & $62 \mathrm{~b}$ & $56 \mathrm{~b}$ & $2.00 \mathrm{bc}$ & $7.92 \mathrm{bc}$ \\
\hline Furfural + AITC & $400 \mathrm{lb}$ & $22 \mathrm{ef}$ & $18 \mathrm{~d}$ & $0.67 \mathrm{f}$ & $2.16 \mathrm{e}$ \\
\hline Furfural (four times) & $6 \mathrm{gal}$ & & & & \\
\hline Furfural and $\mathrm{MNa}$ & $37 \mathrm{gal}+33 \mathrm{gal}$ & 34 cde & $23 \mathrm{~d}$ & $1.03 \mathrm{ef}$ & $3.50 \mathrm{e}$ \\
\hline Furfural (four times) & $6 \mathrm{gal}$ & & & & \\
\hline
\end{tabular}

${ }^{\mathrm{z}} \mathrm{AITC}$, allyl isothiocyanate; $\mathrm{MBr}$, methyl bromide; $\mathrm{MNa}$, metam sodium; 1,3-D, 1,3-dichloropropene; Pic, chloropicrin.

${ }^{\prime} 1 \mathrm{lb} /$ acre $=1.1209 \mathrm{~kg} \cdot \mathrm{ha}^{-1} ; \mathrm{l} \mathrm{gal} / \mathrm{acre}=9.3540 \mathrm{~L} \cdot \mathrm{ha}^{-1} ; \mathrm{l}$ ton $/$ acre $=2.2417 \mathrm{t} \cdot \mathrm{ha}^{-1}$.

xPlant vigor values expressed as a percentage scale where $100 \%$ is optimum plant vigor and $0 \%$ is plant death. Data transformed with arc sine square root before analysis of variance and treatment means were separated with Waller-Duncan multiple comparison procedure $(P \leq 0.05)$. WAT, weeks after transplanting. 
furfural, which had been indicated as an effective nematicide in greenhouse conditions (Rodriguez-Kabana, 2005), failing to control sting nematode effectively in the current study. In summary, this study determined that fumigation programs containing 1,3-D + Pic, Pic and $\mathrm{MNa}$, and fosthiazate and Pic are valuable alternatives to $\mathrm{MBr}+\mathrm{Pic}$ for sting nematode control in strawberry.

\section{Literature cited}

Ajwa, H.A., S. Fennimore, Z. Kabir, F. Martin, J. Duniway, G. Browne, T. Trout, R. Goodhue, and L. Guerrero. 2003a. Strawberry yield under reduced application rates of chloropicrin and inline in combination with metam sodium and VIF. 7 Nov. 2006. <http://mbao.org/2003/ 003\%20ajwahmbao-ajwa03-vif.pdf>.

Ajwa, H.A., S.D. Nelson, and T. Trout. $2003 \mathrm{~b}$. Water and methyl isothiocyanate distribution in soil after drip fumigation with metam sodium. 7 Nov. 2006. <http://mbao.org/2003/037\% 20ajwahmbao-ajwa03-mitc.pdf>.

De Cal, A., A. Martínez-Treceño, J.M. López-Aranda, and P. Melgarejo. 2004. Chemical alternatives to methyl bromide in Spanish strawberry nurseries. Plant Dis. 88:210-214.

Eger, J.E. 2000. Efficacy of Telone products in Florida crops: A seven year summary. 7 Nov. 2006. <http://mbao.org/ altmet00/40eger.pdf>.

Fennimore, S.A., M.J. Haar, and H.A. Ajwa. 2003. Weed control in strawberry provided by shank- and drip-applied methyl bromide alternative programs. HortScience 38:55-61.

Gilreath, J.P., B.M. Santos, P.R. Gilreath, J.P. Jones, and J.W. Noling. 2004. Efficacy of 1,3-dichloropropene + chloropicrin application methods in combination with pebulate and napropamide in tomato. Crop Prot. 23:1187-1191.

Gilreath, J.P., B.M. Santos, T.N. Motis, J.W. Noling, and J.M. Mirusso. 2005. Methyl bromide alternatives for nematode and Cyperus control in bell pepper (Capsicum annuum). Crop Prot. 24:903908.

Jardine, D.J. and T.C. Todd. 1990. The sting nematode. Kansas State Univ. Coop. Ext. Serv. Publ. L-817. Kansas State Univ., Manhattan, KS.

Jenkins, W.R. 1964. A rapid centrifugalflotation technique for separating nematodes from soil. Plant Dis. Rptr. 48:692.

Jones, J.P., J.P. Gilreath, and A.J. Overman. 1995. Control of soil-borne disease of mulched tomato by fumigation. Proc. Florida State Hort. Soc. 108: 201-203.

Locascio, S.J., J.P. Gilreath, D.W. Dickson, T.A. Kucharek, J.P. Jones, and J.W. Noling. 1997. Fumigant alternatives to methyl bromide for polyethylenemulched tomato. HortScience 32:12081211 .

López-Aranda, J.M., L. Miranda, C. Soria, F. Romero, B. de los Santos, F. Montes, J.M. Vega, J.I. Páez, J. Bascón, and J.J. Medina. 2004. Chemical alternatives to methyl bromide for strawberry production in Huelva (Spain), 2003/04 results. 7 Nov. 2006 . <http:// mbao.org/2004/Proceedings 04/ 041\%20LopezArandaJ\%20Spain\%20Exp eriments $\% 20$ Strawberry\%202004\%20 Orlando.pdf $>$.

Mirusso, J., D. Chellemi, and J. Nance. 2002. Field validation of methyl bromide alternatives, 2002. 7 Nov. 2006. <http://mbao.org/2002proc/018 chellemid $\% 20$ large $\% 20$ scale $\% 20$ field $\% 20$ evaluation-mbao2002.pdf>.

Noling, J.W. Nematode management in strawberries. 2005. Inst. Food Agr. Sci.
Publ. ENY-031. Univ. of Florida, Gainesville, FL.

Norton, J.A. 2004. IR-4 methyl bromide alternative (MBA) programs review. 7 Nov. 2006. <http://mbao.org/2004/ Proceedings04/025\%20NortonJ\%20IR4\%202004\%20MBA\%20Presentation. pdf>.

Peres, N.A., J.F. Price, W.M. Stall, C.K. Chandler, S.M. Olson, T.G. Taylor, S.A. Smith, and E.H. Simonne. 2006. Strawberry production in Florida, p. 375-382. In: S.O. Olson and E.H. Simonne (eds.). Vegetable production handbook for Florida, 2006-2007. Inst. Food Agr. Sci. Publ., Univ. of Florida, Gainesville, FL.

Rodriguez-Kabana, R. 2005. Herbicidal and nematicidal properties of drench applications of furfural (2-furfuraldehyde). 7 Nov. 2006 . <http:// mbao.org/2005/05 Proceedings/ 026RodriguezR\%20mbr-sandiego-2005furfural.pdf $>$.

Santos, B.M. and J.P. Gilreath. 2005. Tomato nutrient absorption and nutsedge and sting nematode management with propylene oxide. Proc. Florida State Hort. Soc. 118:166-168.

U.S. Department of Agriculture. 2005. Statistics of vegetables and melons. 14 Feb. 2006. <www.usda.gov/nass/pubs/ agr05/05_ch4.PDF $>$.

Warren, M. 2004. Propozone soil fumigant 2004. 7 Nov. 2006. <http:// mbao.org/2004/Proceedings04/ $022 \mathrm{~A} \% 20 \mathrm{~W}$ arren M $\% 20$ Propozone $\% 202004 \% 20$ soil\%20talks.pdf $>$.

Watson, R.T., D.T. Albritton, S.O. Anderson, and S. Lee-Bapty. 1992. Methyl bromide: Its atmospheric science, technology and economics. Montreal Protocol Assessment Suppl., United Nations Environmental Programme, Nairobi, Kenya. 